\title{
Psikolojik Sahiplik Kavramına ilişkin Bir Literatür İncelemesi
}

\author{
Ümit YEŞiL, Ali BANCAR, Gönül BUDAK*
}

Psikolojik Sahiplik Kavramına İlişkin Bir Literatür İncelemesi

Özet

Bireylerin, sahip olmak istediklerimaddesel veya maddesel olmayan hedefi ya da bu hedefin bir parçasını kendilerininmiş gibi hissetmeleri durumu (Pierce vd., 2001; s. 299) olarak tanımlanan psikolojik sahipliğin temeli, sahiplenme hissine ve bir nesneye veya bir fikre psikolojik olarak bağı olmaya dayanmaktadır. Psikolojik sahiplik, son yıllarda batılı akademisyenler tarafından sıkIıkla tartışlan bir konu haline gelmişken, ülkemizde bu olgu üzerine yapılan çalışmalar oldukça sınırlı sayıdadır. Bu doğrultuda çaıışmanın amacı; psikolojik sahiplik konusunda yapılan çalışmaları değerlendirerek, bugüne dek gelinen noktayı özetleyebilmek, mevcut çalışmalarda öne çıkan noktaları vurgulayarak, bu kavramın daha iyianlaşımasını sağlayabilmek ve ülkemizde bu konuda çalışmak isteyen araştırmacılar için bir başlangıç noktası oluşturabilmektir. Bu bağlamda, psikolojik sahiplik üzerine ilgili yazın taranmış olup, teorik ve/veya uygulamalı çalışmalar dikkatlice incelenerek, psikolojik sahiplik kavramının öncülleri ve çıktıları gruplandırımış ve gelecekte yapılabilecek çalışmalara dair çeşitli öneriler geliştirilmiştir.

Anahtar Kelimeler: Psikolojik sahiplik, sahiplik, sahiplenme
A Literature Review on the Concept of Psychological Ownership

\section{Abstract}

Psychological ownership is defined as a state of mind "in which individuals feel as though the target of ownership (material or immaterial in nature) or a piece of it is theirs" (Pierce et al., 2001; p. 299) and it is based on the feelings of possession and being psychologically tied to an object (or an idea). Psychological ownership phenomenon is commonly studied by western scholars in the recent years, however, the studies on this phenomenon in our country are quite rare. Thus, the purpose of this study is to fill this gap by conducting a comprehensive literature review on psychological ownership, to contribute to a better understanding of this phenomenon and to encourage the scholars in Turkey to pay more attention to it. In this context, through a careful examination of theoretical and applied studies, the antecedents and outcomes of psychological ownership have been grouped and several suggestions over future works have been made.

Key Words: Psychological ownership, ownership, possession

\section{Giriş}

Psikolojik sahiplik kavramı son yıllarda örgüt-işgören denkleminde karanlıkta kalan pek çok noktaya ışık tutabilecek bir olgu olarak görülse de, ülkemizde bu konu üzerindeki araştırmalar sınırlı sayıdadır. Bu eksikliği gidermek adına, bu çalışmada; psikolojik sahipliğin ne olduğu, nasıl ortaya çıktığı ve örgütsel çıktılarının neler olduğu sorularına yanıt aranacaktır. Sözü edilen konuları açıklığa kavuşturmaya, teorinin doğuşundan başlamak yararlı olacaktır.

\footnotetext{
* Ümit Yeşil, Arş.Gör., Dokuz Eylül Üniversitesi, İşletme Bölümü,umit.yesil@deu.edu.tr; Ali BANCAR, Arş.Gör., Dokuz Eylül Üniversitesi, İşletme Bölümü,ali.bancar@deu.edu.tr; Gönül BUDAK,Prof.Dr.,Dokuz Eylül Üniversitesi,İşletme Bölümü,gonul.budak@deu.edu.tr
} 
Özellikle 1970'li yıllardan itibaren çalışanlara hisse vererek onları örgütlerin ortağı yapmaya yönelik finansal sahiplik planları sıkıkla araştırmalara konu olmuş ve olmaya da devam etmektedir. Ancak uygulamada bu planların örgütsel performansa ne kadar yansıdığına ilişkin araştırmalar, oldukça tutarsız sonuçlar vermektedir. Pierce ve Furo (1991) yaptıkları çalışmada, çalışan hisse sahipliği planlarının; iş doyumu, örgütsel bağılık, devamlılık ve örgütsel performans gibi konularda farklı sonuçlar vermesinden yola çıkarak, hangi şartlar altında çalışan hisse sahipliği planlarının pozitif sosyal-psikolojik ve davranışsal sonuçlar üretebileceği sorusuna cevap aramışlardır. Psikolojik sahiplik kavramı ise; bu sorunun cevabı olarak ortaya çıkmaktadır.

Sahiplik; sahip olunan nesneyi sahiplenme hakkı, bu nesneyle ilgili bilgiye erişim hakkı ve bu nesne üzerindeki kontrol hakkı olmak üzere, üç temel hak üzerinden tanımlanmaktadır (Pierce ve Furo, 1991; s. 37). Esasında çalışan hisse sahipliği planlarının farklı çıktılar vermesi, çalışan sahiplerin bu üç temel hakka hangi oranda sahip oldukları ile ilgilidir. Örneğin bir çalışan sahip, aldığı hisse vasıtasıyla örgütün hissedarı olmaktadır. Ancak sadece örgütün hissesine sahip olmak, örgütle ilgili önemli bilgilere erişim hakkı sağlamadığı gibi örgütün karar mekanizması içinde olma hakkı da vermemektedir. Pierce, Rubenfeld ve Morgan (1991), çalışan sahipliği üzerine geliştirdikleri kavramsal modelde bu durumu daha iyi açıklamaktadırlar. Onlara göre sadece sahipliğin yapısı değil, sahiplikle ilgili beklentiler, yönetim felsefesi ve sahipliğin algılanan meşruiyeti de psikolojik sahipliğin oluşmasına ve dolayısıyla bireysel çıktılara etki eden önemli unsurlardır. Psikolojik sahipliğin; çalışan sahipliği üzerine geliştirilen bu kavramsal modeldeki önemli yeri, araştırmacıları bu kavramı daha sık incelemeye itmiştir. Bir başka deyişle, bu çalışma psikolojik sahiplik yazını açısından önemli bir başlangıç noktası olarak görülmektedir.

Pierce ve arkadaşları (1991); işgörenin hisse sahipliği olsa da olmasa da psikolojik sahipliğin yüksek motivasyon sağlayacağını ve ekstra rol davranışlarını - “örgüte yarar sağlayan ve/veya yarar sağlama niyetiyle gerçekleştirilen, isteğe bağlı ve mevcut rol beklentilerinin ötesine geçen davranışlar" (Van Dyne, Cummings ve Parks, 1995; s. 218) - etkileyeceğini öne sürmektedirler. Bu teoriden yola çıkan VandeWalle, Van Dyne ve Kostova (1995); psikolojik sahiplik ve ekstra rol davranışları arasındaki ilişkiyi incelemişlerdir. Bu çalışmada asıl dikkat çeken nokta ise; iş doyumu ekstra rol davranışları ilişkisiyle, psikolojik sahiplik ekstra rol davranışları ilişkisinin kıyaslanmasıdır. VandeWalle ve arkadaşlarının (1995) psikolojik sahiplik ve ekstra rol davranışları ilişkisinin, iş doyumu ekstra rol davranışları ilişkisine kıyasla daha güçlü olduğunu bulgulamaları, psikolojik sahiplik değişkeninin insan örgüt denkleminde karanlıkta kalmış olan pek çok noktaya ışık tutabileceği görüşünü güçlendirmiştir. Bununla beraber, psikolojik sahipliğin teorik çerçevesinin tam olarak oturmaması önemli bir eksiklik olarak ortaya çıktığından, bu eksikliği gidermek adına Pierce, Kostova ve Dirks (2001); psikolojik sahipliği teorileştirme yolunda önemli bir adım atarak, psikolojik sahiplik kavramının tanımını, kökenlerini, ortaya çıkmasını sağlayan yolları -mekanizmaları- ve örgütsel çıktılarını açıklı̆a kavuşturmaya çalışmışlardır. Çalışmanın bir sonraki bölümünde bahsi geçen konular etraflıca tartışılacaktır. 


\section{Psikolojik Sahipliğin Temelleri}

Psikolojik sahipliğin kavramsal çerçevesini oluştururken, öncelikle hedeflerini ve varsayımlarını tanımlamak uygun olabilir. Sahiplik hissi, neredeyse tüm toplumlarda görülmekte ve insanlar bu hisle birlikte, kendileri ile çeşitli soyut ve somut hedefler arasında bağlantılar kurmaktadırlar. Psikolojik sahiplik yazınında hedef kavramı oldukça geniş anlamda kullanılmakta ve birey veya grup için nesne neyi temsil ediyorsa onu nitelendirmektedir (Avey, Avolio, Crossley ve Luthans, 2009; s. 174). Örneğin; ofisteki masa, sandalye, bilgisayar vb. küçük ve somut hedeflere (dar kapsamlı) yönelik sahiplik hissi oluşabileceği gibi, örgütün; misyonu, vizyonu ve hatta bir bütün olarak örgüt de (geniş kapsamlı) sahiplenilebilmektedir.

"Bireylerin, sahip olmak istedikleri hedefi (doğası gereği maddesel veya maddesel olmayan) ya da onun bir parçasını kendilerininmiş gibi hissetmeleri durumu" (Pierce vd., 2001; s. 299) olarak tanımlanan psikolojik sahiplik kavramının temeli; benlik (self), sahiplik (ownership) ve sahiplenilen varlıklar/mülkler (possession) yazınlarına dayanmakta ve sahipliğin psikolojik yönüne vurgu yapmaktadır. Geçmiş araştırmalar incelendiğinde; (a) sahiplik hissinin, insan olma durumunun bir parçası olduğu, (b) insanların, soyut veya somut çok çeşitli varlıklara karşı sahiplik hissi geliştirdikleri ve (c) sahiplik hissinin, önemli davranışsal, duygusal ve psikolojik sonuçları olduğu görülmektedir (Pierce vd., 2001; s. 299). Pek çok araştırmacı, sahiplenilen soyut ve/veya somut varlıkları benliğin bir uzantısı olarak görmekte, çoğu zaman da benliği sahip olunanların bir toplamı olarak tanımlamaktadır (bkz. Litwinski, 1947; Belk, 1988).

Sahiplenme psikolojisi; tutumlarla, benlik kavramıyla ve sorumluluk hissiyle yakından ilişkilidir. Insanlar fikirlere ve nesnelere karşı sahiplik hissettiklerinde onlara karşı tutumları daha olumlu olmakta, onları benliklerinin bir uzantısı olarak görmekte ve onlara yönelik sorumluluk hisleri artmaktadır (Van Dyne ve Pierce, 2004; s. 441).

Psikolojik sahipliğin temelinin bu durumda sahiplenme hissine dayandığı söylenebilir. Psikolojik sahiplik; resmi veya yasal sahiplik iddialarının olmadığı durumlarda ortaya çıkan sahiplenme hissidir (Mayhew, Ashkanasy, Bramble ve Gardner, 2007; s. 477) ve sahiplenmeye dayalı doğası, onu işgören tutum ve davranışlarını açıklamakta hali hazırda var olan yapılardan (örgütsel bağlıık ve iş doyumu gibi) farklılaştırmaktadır (Van Dyne ve Pierce, 2004; s. 440).

Psikolojik sahiplik; yapısal çekirdeği, hizmet ettiği güdüleri, durumsal biçimi gibi yollarla; örgütsel bağlıık, özdeşleşme ve içselleştirme kavramlarından ayrılmaktadır. Psikolojik sahiplik; “Neyin benim olduğunu hissediyorum?" sorusunu sorarken, örgütsel bağılık; "Bu örgütteki üyeliğimi sürdürmeli miyim, öyleyse neden?" sorusunu sormakta, özdeşleşme; "Ben kimim?" sorusuna yanıt aramakta ve içselleştirme ise; “Neye inanıyorum?” sorusuyla ilgilenmektedir. Psikolojik sahiplik, örgütlerdeki insani deneyimlerin eşsiz bir boyutunu tarif ettiğinden, yukarıdaki yapılardan farklılaşmaktadır (Pierce vd., 2001; s. 305). Tablo I'de, psikolojik sahiplik ve diğer yapılar arasındaki ayırt edici noktalar özetlenmektedir. 


\section{Ümit YEŞiL | Ali BANCAR | Gönül BUDAK}

Tablo 1. Psikolojik Sahipliğin Diğer Yapılarla Kıyaslanması

\begin{tabular}{|c|c|c|c|c|c|c|}
\hline $\begin{array}{l}\text { Farklılığın } \\
\text { Boyutları }\end{array}$ & $\begin{array}{l}\text { Psikolojik } \\
\text { Sahiplik } \\
\end{array}$ & Bağlıık & Özdeşleşme & İçselleştirme & $\begin{array}{l}\text { Psikolojik } \\
\text { Güçlendirme }\end{array}$ & $\begin{array}{l}\text { İşle } \\
\text { Bütünleşme }\end{array}$ \\
\hline $\begin{array}{l}\text { Yapısal } \\
\text { Çekirdek }\end{array}$ & $\begin{array}{l}\text { Sahip olma } \\
\text { isteği }\end{array}$ & $\begin{array}{l}\text { Bağlılığı } \\
\text { sürdürme } \\
\text { arzusu }\end{array}$ & $\begin{array}{l}\text { Kendini } \\
\text { tanımlamak } \\
\text { için kimliği } \\
\text { kullanmak }\end{array}$ & $\begin{array}{l}\text { Paylaşılan } \\
\text { amaçlar } \\
\text { değerler }\end{array}$ & $\begin{array}{l}\text { İşteki role uyum } \\
\text { sağlamayı } \\
\text { gerçekleştirmek }\end{array}$ & $\begin{array}{l}\text { Birinin işiyle } \\
\text { özdeşleşmesi }\end{array}$ \\
\hline $\begin{array}{l}\text { Bireye } \\
\text { Sorulan } \\
\text { Sorular }\end{array}$ & $\begin{array}{l}\text { Neyin benim } \\
\text { olduğunu } \\
\text { hissediyorum } \\
\text { ? }\end{array}$ & $\begin{array}{l}\text { Üyeliğimi } \\
\text { sürdürmeli } \\
\text { miyim? }\end{array}$ & Ben neyim? & $\begin{array}{l}\text { Neye } \\
\text { inanıyorum? }\end{array}$ & $\begin{array}{l}\text { İşteki rolümü } \\
\text { şekillendirebilir } \\
\text { miyim? }\end{array}$ & $\begin{array}{lr}\text { İşim benim } \\
\text { için ne } \\
\text { derece } \\
\text { önemli? }\end{array}$ \\
\hline \multirow[t]{2}{*}{$\begin{array}{l}\text { Güdüsel } \\
\text { Temelleri }\end{array}$} & $\begin{array}{l}\text { Etkililik ve } \\
\text { etkinlik }\end{array}$ & $\begin{array}{l}\text { Güvenlik } \\
\text { Ait olma }\end{array}$ & $\begin{array}{l}\text { Cezbediciler } \\
\text { Yakın ilişki }\end{array}$ & $\begin{array}{l}\text { Haklı olma } \\
\text { ihtiyacı }\end{array}$ & $\begin{array}{l}\text { Öz etkinlik } \\
\text { Öz saygı }\end{array}$ & İşin önemi \\
\hline & $\begin{array}{l}\text { Öz-kimlik } \\
\text { Yuva hissi }\end{array}$ & $\begin{array}{l}\text { İnançlar ve } \\
\text { değerler }\end{array}$ & $\begin{array}{l}\text { Kendini } \\
\text { geliştirme }\end{array}$ & $\begin{array}{l}\text { İnançlar } \\
\text { değerler }\end{array}$ & $\begin{array}{l}\text { Bilgiye erişim } \\
\text { Ödüller }\end{array}$ & $\begin{array}{l}\text { Öz saygıуı } \\
\text { tatmin etme }\end{array}$ \\
\hline Gelişim & $\begin{array}{l}\text { Örgüte } \\
\text { benliğini } \\
\text { dayatma } \\
\text { girişimi }\end{array}$ & $\begin{array}{l}\text { Üyeliği } \\
\text { sürdürme } \\
\text { kararı }\end{array}$ & $\begin{array}{l}\text { Yakın ilişki } \\
\text { Benzemeye } \\
\text { çalışma }\end{array}$ & $\begin{array}{l}\text { Örgütsel amaç } \\
\text { ve değerlerin } \\
\text { benimsenmesi }\end{array}$ & $\begin{array}{l}\text { Yetkinliğe } \\
\text { inanmak } \\
\text { Özerklik } \\
\text { Çıktılara etki }\end{array}$ & $\begin{array}{l}\text { İşteki } \\
\text { psikolojik } \\
\text { önem }\end{array}$ \\
\hline $\begin{array}{l}\text { Durum } \\
\text { Türü }\end{array}$ & $\begin{array}{l}\text { Bilişsel/ } \\
\text { duygusal }\end{array}$ & Duygusal & $\begin{array}{l}\text { Bilişsel/ } \\
\text { algısal }\end{array}$ & Bilişsel/nesnel & $\begin{array}{l}\text { Duygusal/algısal } \\
\text { Bilişsel }\end{array}$ & Duygusal/ \\
\hline \multirow[t]{3}{*}{$\begin{array}{l}\text { Sonuçları } \\
\text { (Select } \\
\text { Cons.) }\end{array}$} & $\begin{array}{l}\text { Haklar ve } \\
\text { sorumluluklar } \\
\text { Değişimi }\end{array}$ & $\begin{array}{l}\text { Örgütsel } \\
\text { vatandaşlık } \\
\text { davranışı }\end{array}$ & $\begin{array}{l}\text { Kalma niyeti } \\
\text { Hayal kırıklığı/ }\end{array}$ & $\begin{array}{l}\text { Örgütsel } \\
\text { vatandaşlık } \\
\text { davranışı }\end{array}$ & $\begin{array}{l}\text { Etkin rol } \\
\text { performansı } \\
\text { Konsantrasyon }\end{array}$ & $\begin{array}{l}\text { İçsel } \\
\text { motivasyon }\end{array}$ \\
\hline & $\begin{array}{l}\text { teşvik etme } \\
\text { veya direnç }\end{array}$ & $\begin{array}{l}\text { İşten } \\
\text { ayrılma }\end{array}$ & $\begin{array}{l}\text { stres } \\
\text { Yabancılaşma }\end{array}$ & $\begin{array}{l}\text { İşten ayrılma } \\
\text { niyeti }\end{array}$ & Dirençlilik & Kalma niyeti \\
\hline & $\begin{array}{l}\text { gösterme } \\
\text { Paylaşmayı } \\
\text { reddetme }\end{array}$ & $\begin{array}{l}\text { niyeti } \\
\text { Devamlılık }\end{array}$ & $\begin{array}{l}\text { Performans } \\
\text { Bireyin iyi } \\
\text { olma hali }\end{array}$ & Rol davranışı & $\begin{array}{l}\text { İnovasyon ve } \\
\text { davranış }\end{array}$ & $\begin{array}{l}\text { Düşük } \\
\text { devamsızlık }\end{array}$ \\
\hline \multirow[t]{2}{*}{ Haklar } & $\begin{array}{l}\text { Bilgilendirilm } \\
\text { e hakkı }\end{array}$ & - & - & - & $\begin{array}{l}\text { Anlamlı iş } \\
\text { Bilgiye erişim }\end{array}$ & Anlamlı iş \\
\hline & $\begin{array}{l}\text { Sesini } \\
\text { duyurma } \\
\text { hakkı }\end{array}$ & & & & Ödüller & $\begin{array}{l}\text { Yetecek } \\
\text { kadar } \\
\text { denetim }\end{array}$ \\
\hline
\end{tabular}


Eskişehir Osmangazi Üniversitesi Sosyal Bilimler Dergisi

\begin{tabular}{|c|c|c|c|c|c|c|c|}
\hline $\begin{array}{l}\text { Sorumluluk } \\
\text { lar }\end{array}$ & $\begin{array}{l}\text { Yük paylaşımı } \\
\text { Sesini aktif ve } \\
\text { sorumluluk } \\
\text { sahibi olarak } \\
\text { duyurma }\end{array}$ & - & $\begin{array}{l}\text { Hayranlık } \\
\text { duyulan } \\
\text { tutumu } \\
\text { sürdürme }\end{array}$ & $\begin{array}{l}\text { Amaç } \\
\text { değerlerin } \\
\text { korunması }\end{array}$ & ve & $\begin{array}{l}\text { Eylemleri } \\
\text { beceriklice } \\
\text { yerine } \\
\text { getirebilme }\end{array}$ & - \\
\hline & $\begin{array}{l}\text { Bilgilendirilm } \\
\mathrm{e}\end{array}$ & & & & & & \\
\hline
\end{tabular}

Kaynak: Pierce ve arkadaşlarından (2001) uyarlayan Olckers ve Du Plessis (2012, s. 2587).

\section{1. Psikolojik Sahipliğin Boyutları}

Psikolojik sahiplik geliştirici ve önleyici olmak üzere iki farklı biçimde görülebilmektedir; Pierce ve arkadaşlarının (2001) psikolojik sahipliğin karanlık tarafı olarak nitelendirdiği şeklini, Avey ve arkadaşları (2009) önleyici psikolojik sahiplik başlığı altında ele almakta, psikolojik sahipliğin olumlu şeklini ise; geliştirici psikolojik sahiplik olarak tanımlamaktadırlar.

Higgins'in $(1997,1998)$ düzenleyici odak teorisinden yola çıkan Avey ve arkadaşları (2009; ss. 175-176), psikolojik sahipliğin iki eşsiz ve bağımsız şeklinin, bireylerin gelişme ve önleme olmak üzere, iki farklı öz düzenleme sistemine sahip olmalarından kaynaklandığını öne sürmektedirler. Gelişme odaklı bireyler başarı ve daha büyük amaçlarla ilgilenerek, risk alma konusunda daha istekliyken, önleme odaklı bireyler için görevler ve zorunlulukları gerçekleştirmek ön planda olmakta ve endişe gibi olumsuz duyguları deneyimlemektedirler.

Psikolojik sahiplik açısından bakıldığında, gelişme odaklı bireylerin sahiplenilen hedeflere yönelik hisleri, önleme odaklı bireylerin hislerine kıyasla oldukça farklıdır. Örneğin; değişim ve ilerleme için bilgi paylaşımının önemsendiği durumlarda, gelişme odaklı psikolojik sahipliği bulunan bir yönetici, tamamladığı bir projeyle ilgili sadece kendisinin sahip olduğu bilgileri, şirketteki diğer birimlerle paylaşarak, şirketinin gelişimine katkıda bulunmayı kişisel açıdan tatmin edici bulabilmektedir. Buna karşın, önleme odaklı psikolojik sahipliği olan bireyler ise; mevcut durumu korumak ve değişiklikten kaçınmak için sahip olduğu bilgileri saklayabilmektedirler (Avey vd., 2009; ss. 175-176).

Özetle geliştirici psikolojik sahiplik ve önleyici psikolojik sahiplik, psikolojik sahipliğin iki ana boyutu olarak ortaya çıkmaktadır. Bu ana boyutların her birinin ise; alt boyutları bulunmaktadır. Ancak Pierce ve arkadaşlarının (2001, ss. 299-300), psikolojik sahipliğin kökenleri olarak nitelendirdiği bu alt boyutları açıklamadan önce, psikolojik sahipliğin neden ortaya çıktığı veya bireyi hangi güdülerin bu duruma ittiği sorusu sorulmalıdır. Bir grup araştırmacı bu durumun ortaya çıkışını bireyin genetik yapısına bağlarken - diğer bir ifadeyle bireyin doğasında sahiplenme hissi olduğunu savunurken, diğerleri, yanıtı bireyin erken çocukluk dönemlerinde, yani sosyal yapıda aramaktadırlar. Her ne kadar bu sorunun bilimsel anlamda henüz net bir cevabı olmasa da, Pierce ve arkadaşları, hem genetik hem de sosyal yapının psikolojik sahipliğin oluşmasında etkisine vurgu yapmaktadırlar. Onlara göre psikolojik sahiplik hislerinin gelişmesini sağlayan üç temel güdü vardır; (a) etkililik ve etkinlik (efficacy 
and effectance), (b) öz kimlik (self-identity) ve (c) ait olma/yuva hissi (having a place). Ancak bu güdüler psikolojik sahipliğin nedenleri olarak görülmemekte, daha ziyade sahiplik durumunun neden var olduğunu anlamayı kolaylaştırmaktadır (O'Driscoll, Pierce ve Coghlan, 2006; s. 394).

Yukarıda bahsedilen üç güdüyü aynı zamanda geliştirici psikolojik sahipliğin boyutları olarak değerlendiren Avey ve arkadaşları (2009), hesap verebilmeyi (accountability) geliştirici psikolojik sahipliğin dördüncü boyutu olarak ele almakta ve bölgeciliği ise önleyici psikolojik sahipliğin tek boyutu olarak yazına katmaktadırlar. Psikolojik sahiplik yazınında ağılıkıı olarak yukarıda bahsedilen beş boyut ele alınsa da; Olckers ve du Plessis (2012) geliştirici psikolojik sahipliğin, sorumluluk (responsibility) ve özerklik (autonomy) olmak üzere iki boyutunun daha olduğunu öne sürmektedirler. Bu boyutlar aşağıda kısaca açıklanmaktadır.

\subsubsection{Etkililik ve Etkinlik}

Sahiplenmenin temelinde yatan güdü, kontrolü elinde bulundurmaktır. Bireylerin herhangi bir şey üzerindeki kontrolleri veya çeşitli eylemleri yerine getirebilme inisiyatiflerinin olması, etkililik hissini ortaya çıkarmaktadır. Sahiplik ve beraberinde gelen haklar, bireylerin çevrelerini keşfetmelerine ve onu değiştirmelerine imkan vererek etkili olma ihtiyaçlarını tatmin etmelerini sağlamaktadır. Bireylerin çevrelerini değiştirmeye yönelik bu arzuları, onların sahiplenme girişimlerinde bulunmalarına ve bu sayede sahiplik hissinin oluşmasına yol açmaktadır (Pierce vd., 2001; s. 300). Bireylerin

eylemlerini kontrol edebilme özgürlükleri, öz etkillik hislerini tetikleyerek belirli bir göreve, sürece ve işleme yönelik psikolojik sahiplik hissinin oluşmasını sağlayabilmektedir (Avey vd., 2009; s. 177).

\subsection{2. Öz Kimlik}

Farklı disiplinlerden (psikoloji, sosyal psikoloji, antropoloji, felsefe, insan gelişimi vb.) pek çok araştırmacı sahiplik ve benlik arasında bir ilişki olduğunu öne sürmektedirler (Pierce ve Rodgers, 2004; s. 598). Dittmar (1992); bireylerin çeşitli hedefler ve benlikleri arasındaki bağlantıyı psikolojik olarak deneyimlediklerini belirtmekte, Isaacs (1933) ise; bireylerin sahip olduklarının onların bir parçası haline geldiğini vurgulamaktadır (Pierce vd., 2001; s. 299).

Sahiplenilenler, bireylerin kimliklerine eklenen önemli unsurlar ve kimliklerinin yansımalarıdırlar (Belk, 1988; s. 139). Onlarla olan etkileşimler ve onlara atfedilen anlamlar kimlik hissini ve bireyin kendini nasıı tanımladığını etkilemektedir. Buradan yola çıkan Pierce ve arkadaşları (2001, s. 300); bireylerin sahipliği; kendilerini tanımlamak, öz kimliklerini diğerlerine göstermek ve benliklerinin zaman içindeki devamlıı̆ı̆ıı garanti altına almak amacıyla kullandıklarıı öne sürmektedirler.

\subsubsection{Ait Olma / Yuva hissi}

Psikolojik sahiplik bireyin belirli bir alana sahip olma güdüsüyle de açıklanabilmektedir. Ardrey'e (1966) ve Duncan'a (1981) göre, ait olma hissi sahiplik hisleriyle yakından ilişkilidir (Asatryan ve Haemoon Oh, 2008; s. 368). Bir alana sahip olma hissi - diğer bir tanımla yuva hissi - insan ruhunun 
önemli bir ihtiyacı olup, yerleşilen yer bir nesne olmaktan çıkarak bizim bir parçamı haline gelmektedir. Bu sebeple bireyler, yuva hissi yaratabilecek nesnelere, enerji ve kaynak harcayarak, sahiplik aracılığıyla ait olma güdülerini tatmin etmektedirler (Pierce vd., 2001; s. 300).

\subsubsection{Hesap verebilme}

"Accountability" kavramı oldukça karmaşık bir kavram olarak ele alınmakta ve hesap verebilme, sorumluluk gibi birçok anlamı bünyesinde barındırmaktadır. Kavram genel olarak bir kişinin eylemleri neticesinde bir otoriteye hesap verme gerekliliğini ifade etse de; son yıllarda, akademik yazında daha çok bireysel sorumluluğu ve toplum yararını gözetmeyi ifade eden içsel bir his olarak ele alınmaktadır (Mulgan, 2000; ss. 555-556).

Avey ve arkadaşlarına (2009, s. 177) göre hesap verebilme; diğerlerini sorumlu tutabilme hakkı ve birinin eylemleri vasıtasıyla sorumlu tutulabileceği beklentisi şeklinde iki mekanizma vasıtasıyla psikolojik sahipliğin bir unsuru olarak görülmektedir. Örneğin; futbol kulübü sahipleri takımın performansından teknik direktörü ve oyuncuları sorumlu tutabilirken, medya ve taraftarlara karşı da kendilerini sorumlu tutabilmektedirler. Daha açık bir ifadeyle; psikolojik sahipliğin hesap verebilme unsuru aracılığıyla bireyler hem başkalarını sorumlu tutabilme hakkına sahip olduklarını düşünmekte, hem de içsel olarak öz-sorumluluk hissi taşımaktadırlar. Diğerlerini sorumlu tutma hakkı ve öz-sorumluluk hissi Pierce ve arkadaşlarının (2001; ss. 302-303) psikolojik sahiplikle birlikte gelen haklar ve sorumluluk hissiyle de paralellik göstermektedir. Pierce, Kostova ve Dirks'e (2003, ss. 5-6) göre; psikolojik sahiplikle birlikte gelen haklar bireyin algılarına göre şekillendiğinden, yasal sahiplik ve psikolojik sahipliğin getirdiği haklar birbirlerinden farklı olabilmektedir. O halde, bir hedefe yönelik yüksek derecede psikolojik sahiplik hissi geliştiren bireylerin, bu hedefe etkisi olabilecek diğer kişileri eylemlerinden mesul tutabilmesi muhtemeldir. Buna ek olarak, bireyler sadece başkalarını sorumlu tutma hakkına sahip olma beklentisini taşımamakta, aynı zamanda yükünü paylaşma hissi olarak da adlandırılan kendilerine karşı sorumluluk beklentileri içine de girmektedirler. Sahiplenilenler aynı zamanda benliğin uzantıları olarak görüldüğünden, bir anlamda hem hedeflere hem de benliğe yönelik sorumluluk hissi ortaya çıkmaktadır (Avey vd., 2009; s. 177).

Görüldüğü üzere, hesap verebilme kavramı içsel bir sorumluluk hissini de bünyesinde barındırmaktadır. Bu durumda, Olckers ve du Plessis'in (2012) neden sorumluluğu hesap verebilme boyutundan ayrı olarak değerlendirdiği konusuna açıklık getirmek gerekmektedir. Esasen, Olckers ve du Plessis (2012, ss. 2589-2590); bu farkın bireyin gönüllü olarak sorumluluk alıp almamasından kaynaklandığını belirtmektedir. Sorumluluk, bazen üçüncü kişilerin zorlamasıyla da yüklenilebilmekteyken; hesap verebilme kavramı, bireyin gönüllü olarak sorumluluğu yüklenmesini ifade etmektedir. Bir başka deyişle, aşağıda ele alınan sorumluluk kavramı; bireyin hesap verme zorunluluğu olmasa da sorumlu olabileceği anlamına gelmektedir.

\subsubsection{Sorumluluk}

Sahiplenilen hedefler beraberinde davranışları etkileyen bir sorumluluk hissi ortaya çıkarmaktadır. Diğer bir ifadeyle; sorumluluk hissi sahiplik hissine eşlik etmektedir (Pierce vd., 2001; s. 303). Sorumluluk hissi sahiplenilen hedefe zaman ve enerji harcamayı içermektedir. Örneğin; örgütlerini 
Ümit YEŞiL | Ali BANCAR | Gönül BUDAK

sahiplenen bireyler örgütlerinin gelişimi için çaba göstermektedirler (Olckers ve du Plessis, 2012: s. 2590; Pierce vd., 2001: s. 303).

Sorumluluk ve psikolojik sahiplik arasında karşılıklı bir ilişki olduğunu öne sürmek mümkündür. Sahiplik hissinin sorumluluk hissini doğurabileceği gibi, sorumluluk da sahipliğin ortaya çıkmasında önemli bir etken olabilmektedir. Pierce ve arkadaşları (2003, s. 17) usta - çırak ilişkisini buna örnek olarak göstermektedir. Çırağını geliştirme sorumluluğunu hisseden usta; zamanını, enerjisini, duygularını ve hatta kendi değerlerini çırağına aktarmaktadır ve zamanla diğer kişiyi “kendi çırağı” olarak düşünmeye başlamaktadır. Diğer bir ifadeyle, usta çırağına yönelik psikolojik sahiplik hissi geliştirmekte ve çırağında kendini görmektedir.

\subsection{6. Özerklik}

Özerklik kavramı bireyin kendi kendini yönetmesi ve kendisi tarafından yapılan düzenlemeyi gerçek öz düzenlemeyi - ifade etmektedir (Ryan ve Deci, 2006; ss. 1562-1563). İşgörenlerin özerklik algılarının ve ne derece kontrol sahibi olduklarının örgütsel bağlıık gibi olumlu çıktılar üzerinde önemli etkileri vardır (Olckers ve du Plessis, 2012; s. 2590). Benzer şekilde psikolojik sahiplik, özerklik ve kontrol arasında da önemli ilişkiler bulunmaktadır. Pierce ve arkadaşları (2004) iş çevresi ve psikolojik sahiplik üzerine yaptıkları çalışmada; kontrolün, özerklik ve psikolojik sahiplik arasında aracı bir rol üstlendiğini bulgulamışlardır. Mayhew ve arkadaşları (2007) özerkliğin; hem örgüte, hem de işe yönelik psikolojik sahiplikle ilişkisi olduğunu ortaya koymuşlardır. Özerklik, kontrol ve psikolojik sahiplik arasındaki bu ilişkisel ağ sebebiyle Olckers ve du Plessis (2012), özerkliğin psikolojik sahipliğin boyutları arasında yer alması gerektiğini öne sürmektedirler.

\subsubsection{Bölgecilik (Territoriality)}

Bölgecilik; "bireyin fiziksel veya sosyal bir nesneye yönelik sahiplik hislerinin davranışsal dışavurumu" olarak tanımlanmaktadır (Brown, Lawrence ve Robinson, 2005; s. 578). Örgüt üyeleri; fiziksel alanlar, fikirler, roller, ilişkiler vb. potansiyel hedefleri sahiplenebilmeleri sebebiyle bölgeci davranışlar sergileyebilmektedirler ve bu bölgeci his ve davranışların, örgütler açısından olumlu veya olumsuz sonuçları olabilmektedir. Bölgecilik; bir yandan sosyal gruplara aidiyet hissini meydana getirmesiyle işgücü devir oranında azalma ve performans artışı gibi örgütsel çıktılar sağlayabilirken; diğer bir yandan, işgörenlerin mülkiyet iddialarıyla fazla meşgul olmaları, onların görev performanslarına ve örgütsel amaçlara odaklanmalarını engelleyebilmektedir (Brown vd., 2005; ss. 577-578).

Brown ve arkadaşlarına (2005, ss. 578-579) göre; psikolojik sahiplik ve bölgecilik arasında önemli bir bağ bulunmaktadır. Onlara göre psikolojik sahiplik bölgeci davranışların öncülüdür ve psikolojik sahipliği yüksek olan bireylerin bölgeci davranışlar sergilemesi daha olasıdır. Ancak bu çalışmada bölgeciliğin davranışsal yönüne vurgu yapılmakta ve bölgecilik, psikolojik sahipliğin bir çıktısı olarak görülmektedir. Avey ve arkadaşları $(2009$, s. 177) ise; psikolojik sahipliğin bilişsel ve duygusal 
yapısını göz önünde bulundurarak, bölgeciliğin bilişsel unsurlarına odaklanmakta ve bölgeciliği önleyici psikolojik sahipliği ortaya çıkaran bir unsur ve psikolojik sahipliğin ayrı bir boyutu olarak ele almaktadırlar.

Avey ve arkadaşlarına (2009, s. 177) göre; bölgecilik hissi ve psikolojik sahipliğin gelişme odaklı boyutları arasında iki önemli ayırt edici etmen vardır: (a) bölgecilik için dışsal bir referansın kullanılması ve (b) savunmacılık. Sahip oldukları nesnelerin dışsal kaynakların müdahalelerine maruz kalma intimallerinden korkan bireylerin bölgecilik hissi de artabilmektedir. Önleyici odaklı olunduğu durumlarda, bireyler bölgelerini potansiyel tehditlere karşı işaretlerler. Bölgecilik; çalışma grubunun yararını geliştirmekten çok, önleyici olmaya eğilimlidir.

Bölgecilik; insanların performansları veya diğer toplum yanlısı (prososyal) davranışları pahasına, sahip olduklarıyla fazla meşgul olmalarına yol açmakta ve iş birliği, bilgi paylaşımı gibi örgüt yararına olabilecek konularda, benlik ve sosyal kimlikle bütünleştirilen bölgelerini kaybetme korkuları sebebiyle önleyici davranışlar göstermelerine neden olmaktadır. Ancak takım esaslı çalışmadan çok bireysel çalışmanın önemli olduğu durumlarda, bireyler bölgelerini koruyarak doğru olanı yaptıklarına inanabilmekte ve bireysel performans artışı görülebilmektedir. Diğer bir ifadeyle, genellikle olumsuz olarak görülen bölgeci psikolojik sahipliğin bile olumlu katkıları olabilmektedir (Avey vd., 2009; s. 177).

\section{Psikolojik Sahipliğin Oluşumu}

Yukarıda, psikolojik sahipliğin ne olduğu tanımlanmış ve kavramın köklerine inilmişti. Burada ise; psikolojik sahipliğin nasıl oluştuğu incelenecektir. Pierce ve arkadaşlarına (2001) göre; kontrol, hedefi yakından tanımak ve hedefe odaklanmak (investing the self into the target), psikolojik sahipliği ortaya çıkaran üç temel mekanizmadır, ancak her ne kadar birbirlerinden ayrı olarak ele alınsalar da, bu mekanizmaların birbirleriyle ilişkili olma potansiyeli de bulunmaktadır (Pierce vd., 2001; s. 301). Bu mekanizmalara ek olarak; hedefe, bireye ve süreçlere ilişkin unsurların yanında, bağlamsal öğeler de psikolojik sahipliğin oluşumunda önemli bir rol oynamaktadır. Dolayısıyla, psikolojik sahipliği daha iyi anlamak adına, yukarıda bahsedilen üç mekanizma ve psikolojik sahipliğin oluşumunda etkili olan diğer faktörler aşağıda incelenmektedir:

\section{1. Kontrol}

Bir nesneyi kontrol edebilmek, sahiplik olgusunun temel özelliklerinden biri olarak görülmektedir. Nitekim Rudmin ve Berry (1987) yaptıkları çalışmada, sahipliğin temelde nesneleri kontrol edebilme ve kullanabilme anlamına geldiği sonucuna varmışlardır (Pierce vd, 2001; s. 301). Benzer şekilde diğer araştırmacılar (Csikszentmihalyi ve Rochberg-Halton, 1981; Dixon ve Street, 1957; Sartre, 1969; Tuan, 1980, 1984; White, 1959; Furby, 1976; McClelland, 1951; Rochberg-Halton, 1980; Sartre, 1943) da; bir nesne üzerindeki kontrolün o nesneye yönelik sahiplik hislerinin geliştirilmesinde önemli bir rolü olduğunu vurgulamaktadırlar (Pierce vd., 2001, s. 301; Pierce vd., 2003, s. 14). Ayrıca, kontrol edilebilen nesneler, benliğin bir parçası gibi görülmekte ve nesne üzerindeki kontro- 
Ümit YEŞiL | Ali BANCAR | Gönül BUDAK

lün derecesi arttıkça benliğin bir parçası olma intimali de artmaktadır. Kontrol edilemeyen veya başkaları tarafından kontrol edilen nesneler ise, benliğin parçası olarak görülmemektedir (Pierce vd., 2001, s. 301; Pierce vd., 2003, ss. 14-15).

Görüldüğü üzere, kontrol mekanizmasıyla psikolojik sahipliğin oluşumu, etkililik ve öz-kimlik güdüleriyle yakından ilişkilidir. Kontrol, bireyin hem etkili olma ihtiyacını gidermesini sağlamakta, hem de kontrol edilen nesnelerin benliğin bir parçası olması sonucunu doğurmaktadır. Dolayısıyla, örgütteki bireylerin; örgütlerine, işlerine veya örgüt içerisindeki diğer hedeflere yönelik psikolojik sahiplik hissi geliştirmelerinde, bireylerin algıladıkları kontrol derecelerinin önemli bir rolü vardır. Örneğin; merkezi örgütler ve ademi merkezi örgütler kıyaslandığında, örgütsel yapıdaki merkezileşme ve biçimselleşme dereceleri, kontrol derecelerini de önemli ölçüde belirlemektedir. Daha merkezi yapılarda işgörenlerin işlerindeki özerkliği ve kararlara katıımı sınırı seviyelerde kalırken, merkezilikten uzaklaştıkça bu durum değişmekte ve algılanan kontrol derecesi de artmaktadır. O halde; "bir işgörenin, örgütteki belirli bir unsur üzerindeki kontrol derecesi ve bu unsura yönelik geliştirdiği sahiplik hissi arasında anlamlı ve nedensel bir ilişki olduğunu" öne sürebilmek mümkündür (Pierce vd., 2001; s. 301).

\subsection{Hedefi Yakından Tanımak}

Psikolojik sahipliğin oluşumunda etkili olan bir diğer mekanizma; bireyin hedefle olan birlikteliği, onun hakkında bilgi sahibi olması ve onu daha yakından tanımasıdır. Bireyin bir nesneyle olan bağlantısı (Sartre, 1969) veya onunla canlı bir ilişki kurması (James, 1890) bu nesneye yönelik sahiplik hissi oluşmasını sağlamaktadır (Pierce vd., 2001; s. 301). Öyle ki; bireyin nesneyle olan birlikteliği, üçüncü kişilerin bireyin sahiplik durumuna yönelik algılarını etkilemektedir (Beggan ve Brown, 1994; s. 7).

Beaglehole’a (1932) göre bir nesneyi, kişiyi veya mekanı daha yakından tanıdıkça bu nesne, kişi veya mekan, benlikle bütünleşmektedir (Pierce vd., 2001; s. 301). Weil (1952) bu durumu bahçıvan örneğiyle açıklamaktadır (Pierce vd., 2001, s. 301; Pierce vd., 2003, ss. 15-16). Bahçıvan her ne kadar bahçede bir çalışan olsa da, belirli bir süre sonra bahçenin kendisine ait olduğunu hissetmektedir. Dolayısıyla, bireylerin hedeflerle olan birlikteliği, bir süre sonra onları daha yakından tanımalarını ve onlar hakkında daha fazla bilgi sahibi olmalarını sağlamaktadır. Bireyin bu hedef hakkındaki bilgisi derinleştikçe, benlik ve hedef arasındaki bağlantı da güçlenmekte ve bu sebeple hedefe yönelik sahiplik hissi de artmaktadır (Pierce vd., 2001, s. 301; Pierce vd., 2003, s. 16).

Özetle, bireyler ve hedefler arasındaki bağlantı veya birliktelik psikolojik sahipliğin oluşumunda önemli bir mekanizma olarak ele alınmaktadır. Bireyin hedefle olan birlikteliği veya onunla geçirdiği zaman; bireyin hedef hakkındaki bilgi düzeyini arttırmakta, onu daha yakından tanımasını sağlamakta, bu hedefe odaklanmaya zemin hazırlamakta ve bu sayede hedefe yönelik psikolojik sahiplik hissinin gelişmesine yol açmaktadır. Dolayısıyla, işgörenlerin örgütlerindeki somut veya soyut hedef- 
ler (yapılan işler, projeler, süreçler, örgütün amaçları vb.) hakkında bilgi sahibi olmaları ve bu hedefleri daha yakından tanımaları, bu hedeflere yönelik sahiplik hislerinin gelişmesinde etkili bir rol oynamaktadır (Pierce vd., 2001; ss. 301-302).

\subsection{Hedefe Odaklanma}

Psikolojik sahiplik durumunun ortaya çıkmasında etkili olan bir diğer mekanizma ise bireyin hedefe odaklanmasıdır. Nitekim yüzyıllar öncesinde John Locke (1690), insanların yarattıkları, şekil verdikleri ve ürettikleri şeylere karşı sahiplik hissetmelerinin olası olduğunu öne sürmüştür (Liu, Wang, Hui ve Lee, 2012, s. 869; Pierce vd., 2003, s. 16). Marx (1976) bireylerin emekleri vasıtasıyla yarattıkları ürünlere enerjilerini harcadıklarını ve bunun sonucunda da bu ürünlerin benliğin temsilcileri olduğunu savunmaktadır (Pierce vd., 2001; s. 302). Sartre (1943) ise; bir nesneyi satın almayı bile, bireyin emeğinin bir karşıl lı̆ı ve yaratmanın başka bir şekli olarak değerlendirmekte ve bu sebeple benliği temsil ettiğini öne sürmektedir (Pierce vd., 2003; s. 17). Csikszentmihalyi ve Rochberg-Halton'a (1981) göre, bireyin; enerjisini, çabasını, zamanını ve dikkatini bir nesneye harcaması, nesneyle benliğin bütünleşmesini sağlamakta ve bu nesneye yönelik sahiplik hisleri geliştirmelerine yol açmaktadir (Pierce vd., 2001; s. 302).

Pierce ve arkadaşlarına (2001, s. 302) göre hedefe odaklanma; bireyin zamanını, fikirlerini, becerilerini ve fiziksel, psikolojik veya entelektüel enerjilerini aktarması gibi pek çok değişik şekilde gerçekleşebilmektedir. Ancak, yaratmak; bireyin zamanını, enerjisini ve hatta kişisel değerleri ve kimliğini aktarmayı da içerdiğinden, bu odaklanmanın en güçlü yolu olarak görülmektedir (Pierce vd., 2001, s. 302; Pierce vd., 2003, s. 17). O halde; bir sanatçının ortaya çıkardığı esere, bir bilgisayar programcısının geliştirdiği bir yazılıma, bir akademisyenin yazdığı makaleye veya bir girişimcinin kurduğu şirkete yönelik sahiplik hisleri geliştirebileceğini söyleyebilmek mümkündür. Benzer şekilde, örgüt içerisindeki bireylerin de; emeklerini, zamanlarını, enerjilerini potansiyel hedeflere (işler, ürünler, müşteriler, projeler, çalışma takımları vb.) aktararak, bu hedeflere yönelik psikolojik sahiplik hisleri geliştirmeleri oldukça muhtemeldir.

Daha önce sözü edilen ve psikolojik sahipliğin boyutlarından biri olarak ele alınan sorumluluk hissi de, psikolojik sahipliğin oluşumunda önemli bir rol oynamaktadır. Hedefe yönelik sorumluluk hissi, bireyin hedefe odaklanması sonucunu doğurmakta ve psikolojik sahiplik hislerinin gelişmesini sağlamaktadır (Pierce vd., 2003; s. 17).

\subsection{Diğer Faktörler}

Kontrol, hedefi yakından tanımak ve hedefe odaklanma psikolojik sahipliği ortaya çıkaran üç önemli mekanizma olsa da, psikolojik sahipliğin oluşumunu tek başlarına açılamamaktadırlar. Hedefe ve bireye ilişkin faktörlerin yanında, durumsal faktörler de psikolojik sahipliğin ortaya çıkmasında etkili olmaktadırlar. Ayrıca psikolojik sahipliğin gerek kökenleri, gerekse mekanizmaları arasındaki karmaşık ilişkiler ağı da psikolojik sahipliğin oluşum sürecinde ele alınması gereken noktalar olarak öne çıkmaktadır (Pierce vd., 2003; s. 17). 
Ümit YEŞiL | Ali BANCAR | Gönül BUDAK

\subsubsection{Hedefe ilişkin Unsurlar}

Çalışmanın önceki bölümlerinde, psikolojik sahiplik yazınında hedef kavramının oldukça geniş bir kullanım alanı olduğundan söz edilmişti. Ancak, "bireylerin psikolojik olarak bağlandıkları hedefleri tanımlamaya yönelik pek çok girişim olsa da, ortada ne bir hedef sahipliği teorisi, ne de genel geçer bir hedef sahipliği sınıflandırması mevcuttur" (Pierce vd., 2003; s. 18). Kültürel ve bireysel değerler (Furby, 1976), bireyin yaşam döngüsü (Kamptner, 1991), toplumsal cinsiyet rolleri (Kamptner, 1991; Rochberg-Halton, 1980) vb. faktörler sahiplenilebilecek hedeflerin belirlenmesinde etkili olsa da, sahiplik psikolojisini ortaya çıkaran hedefler daha çok; kontrol edilebilen, yakından tanınabilen ve odaklanılabilen hedeflerdir (Pierce vd., 2003; s. 18).

Pierce ve arkadaşlarına (2003, ss. 18-19) göre, psikolojik sahipliğin kökenleri ve sahipliği ortaya çıkaran mekanizmalar vasıtasıyla hangi özellikleri taşıyan hedeflerin sahiplenebileceği açıklanabilmektedir. Bireyler; (a) psikolojik sahipliğin kökenleri olan üç temel güdüyü tatmin etme potansiyeli olan ve (b) psikolojik sahiplik hislerinin oluşumunu sağlayan mekanizmaların işleyişini kolaylaştırma kapasitesine sahip hedeflere yönelik sahiplik hisleri geliştirmektedirler. Dolayısıyla, hedefin çekiciliği, erişilebilirliği, açıklığı vb. özellikleri, onları psikolojik sahipliğin ideal adayları haline getirmektedir. Çünkü önemli olan, sahiplenilen hedeflerin üç temel güdüyü (etkililik ve etkinlik, öz-kimlik, yuva hissi) ne derece tatmin edebildiğidir. Benzer şekilde; psikolojik sahipliği ortaya çıkaran mekanizmaların (kontrol, hedefi yakından tanımak, hedefe odaklanma) işleyişini kolaylaştıran hedefler de, sahiplik için ideal hedeflerdir. Örneğin, kontrol açısından bakıldı̆̆ında, bir akademisyenin üzerinde çalıştığı projeye yönelik sahiplik hissi geliştirmesi, çalıştığı üniversitesine yönelik sahiplik hissi geliştirmesine kıyasla daha olasıdır. Çünkü sonuçta, akademisyenin kendi projesi üzerinde kontrolü daha fazla olacaktır.

\subsubsection{Bireysel Unsurlar}

Pierce ve arkadaşlarına (2003, s. 19) göre; bireylerin içsel etkililik ve etkinlik, öz-kimlik ve ait olma güdüleri onları psikolojik sahipliğe hazır hale getirse de, bu süreçte bireysel farklılıkların önemli bir yeri vardır. Bireylerin hem güdülerinin şiddeti, hem de kişilikleri açısından farklılık göstermesi, psikolojik sahipliğin oluşumunu, önemli ölçüde etkileyebilmektedir. Örneğin; dışa dönük bireylerin, sosyal anlamlar taşıyan hedeflere yönelik sahiplik hissi geliştirmeleri, içe dönük bireylere kıyasla daha olasıdır. Aynı şekilde, otoriter kişiliğe sahip bireyler, kontrol ve güç deneyimleyebilecekleri hedeflere yönelebilmektedirler. Güçlü benlik hissine sahip bireyler, içsel hedefler peşinde koşabilirken, zayıf benlik hissine sahip bireyler ise; daha çok maddesel hedeflere yönelmektedir.

Bireysel değerlerin de sahiplik sürecinde önemli bir rolü vardır. Sahiplik; öz-değerleme ve özsaygı geliştirmenin araçlarından biri olarak ele alınmaktadır. Dolayısıyla bireylerin, kendi değerlerine göre hangi hedefin daha önemli olduğunu düşünerek, o hedefe yönelik sahiplik hisleri geliştirmeleri daha olasıdır. Entelektüelliğe değer veren bir bireyin kitaplara veya sanat eserlerine yönelik sahiplik hissi geliştirmesi, buna iyi bir örnektir (Pierce vd., 2003; s. 20). 


\subsubsection{Süreç}

Pierce ve arkadaşlarına (2003, s. 20) göre; psikolojik sahipliğin oluşum süreci, daha önce ele alınan faktörler arasındaki etkileşim sebebiyle oldukça karmaşık bir yapıya sahiptir. Psikolojik sahipliğin kökenleri olarak ele alınan üç güdü, yapısal olarak farklı olsa da, birbirlerinden tamamen bağımsız değildir. Bu sebeple, yuva hissi; diğer iki güdüden bağımsız olsa da, tatmin edildiğinde diğer güdüleri kuvvetlendirebilmektedir. Örneğin; bireyler ev olarak gördükleri bir mekanda, daha etkili olduklarını hissedebilirler. Benzer şekilde, yuva hissi kimliğin devamlılı̆ının sağlanmasına da hizmet edebilmektedir.

Pierce ve arkadaşlarına (2003, s. 20) göre; psikolojik sahipliğin kökenleri ve oluşumunu sağlayan mekanizmalar, doğaları gereği; farklı, tamamlayıcı ve ekleyicidirler. Dolayısıyla, etkililik ve etkinlik, özkimlik ve yuva hissi ihtiyaçlarından herhangi birinin tatmin edilmesi sonucunda psikolojik sahiplik ortaya çıkabilmektedir. Ancak bu ihtiyaçlardan birden fazlası bir arada tatmin edildiğinde, daha güçlü sahiplik hisleri oluşması muhtemeldir. Benzer bir durum mekanizmalar için de geçerlidir. Hedefe yönelik sahiplik hissi birden fazla mekanizma vasıtasıyla geliştiğinde, sahiplik durumunun daha güçlü olması muhtemeldir.

Psikolojik sahipliğin oluşum süreciyle ilgili akla gelen bir diğer soru ise; psikolojik sahiplik durumuna ulaşılması için geçen süredir. Psikolojik sahiplik durumunun ortaya çıkması için bilişsel ve duygusal sürecin tamamlanması gerekmektedir. Bilişsel düzeyde sahiplik durumuna geçiş oldukça hızlı olabilmekteyken, sürecin tamamlanması için bireyin sahiplik hissinin de gelişmesi gerekmekte ve dolayısıyla süreç; uzun, dinamik ve tekrarlayıcı olabilmektedir. Bu durum aynı zamanda yasal ve psikolojik sahiplik arasındaki önemli bir ayrımı da göstermektedir. Herhangi bir mülk yasal olarak sahiplenildiği andan itibaren yasal sahiplik ortaya çıkarken, psikolojik sahiplik durumundan söz edebilmek için öncelikle bilişsel/duygusal sürecin tamamlanması gerekmektedir. Bununla beraber, yasal sahiplikle birlikte gelen haklar, psikolojik sahipliğin oluşum mekanizmalarını tetikleyeceğinden, psikolojik sahiplik sürecinin hızlanması olasıdır (Pierce vd., 2003; ss. 21-22).

Psikolojik sahiplik sürecini hızlandırabilecek bir diğer unsur ise; bireylerin sahip oldukları varlıkları gösterme, kullanma ve kişiselleştirme biçimleri gibi kişiden kişiye farklılaşan ritüellerdir. Bu ritüeller vasıtasıyla, bireyin hedefe yönelik yuva hissi geliştirmesi ve nihayetinde hedefi "kendine ait" olarak görmesi oldukça muhtemeldir (Pierce vd., 2003; ss. 22-23).

Psikolojik sahiplik süreciyle ilgili akla gelen bir diğer soru ise; psikolojik sahipliğin ne kadar süreceği veya ne zaman biteceğidir. Psikolojik sahiplik durumunun ortadan kalkması, onu ortaya çıkaran süreçle benzer şekilde işleyecektir. Daha açık bir ifadeyle, bireyin sahipliği ortaya çıkaran kökenler, mekanizmalar, hedef ve bireye ilişkin faktörler ve bunlar arasındaki karşılıklı ilişkilerle bağının kopması sonucunda psikolojik sahiplik durumu da ortadan kalkacaktır. Bireyin hedef üzerindeki kontrolünün azalması, hedefin artık benliğin bir parçası olarak görülmemesi veya başka bir hedefin sahiplik geliştirilen hedefin yerini alması bu sonucu ortaya çıkaracak nedenlere örnek olarak verilebilir (Pierce vd., 2003; s. 23). 


\subsubsection{Bağlamsal Unsurlar}

Pierce ve arkadaşları (2003, ss. 23-28) psikolojik sahipliğin oluşumunu etkileyebilecek pek çok bağlamsal faktör olabileceğini kabul etmekle birlikte, özellikle yapısal ve kültürel bağlam üzerinde durmaktadırlar. Gerek yapısal, gerekse kültürel faktörler psikolojik sahiplik durumunun oluşumunda etkili olabilecek etmenler olarak görülse de, bağlamsal unsurlar ve psikolojik sahiplik üzerine yapılan ampirik çalışmalar sınırlı sayıdadır.

Kurallar, normlar, hiyerarşi gibi yapısal unsurlar, psikolojik sahiplik hissinin gelişmesini veya engellenmesini belirleyebilme potansiyeline sahiptir. Kurallar ve normların fazla sayıda olduğu, işlerin standartlaştırıldığı, bireylerin homojen davranışlar sergilemelerinin beklendiği katı ve mekanik yapılar; hem bireylerin psikolojik sahiplik için gerekli olan güdülerini bastırmalarına neden olabilmekte, hem de psikolojik sahipliğin ortaya çıkmasını sağlayacak mekanizmaları sekteye uğratabilmektedirler (Pierce vd., 2003; ss. 24-25). Mekanik yapılarda bireylerin kontrol dereceleri sınıllandırılmaktadır. Bu durumda hedefleri kontrol edemeyen bireylerin onlara yönelik sahiplik hisleri geliştirmeleri pek olası gözükmemektedir. Benzer şekilde hedefleri kontrol edemeyen bireyler etkililik ve etkinlik ihtiyaçlarını da tatmin edememektedirler. Bunun aksine, kuralların az sayıda olduğu, yaratıcılığa ve özerkliğe elverişli esnek ve organik yapılarda; algılanan kontrol derecesi daha fazla olduğundan, bireyler hem etkililik ve etkinlik ihtiyaçlarını tatmin edebilmekte hem de, kontrol mekanizması vasıtasıyla psikolojik sahipliğin oluşumunu kolaylaştırmaktadırlar. Ayrıca yaratıcılığa elverişli olması, bireylerin öz-kimlik ihtiyaçlarını tatmin edebilmelerinin yanında, hedefe odaklanmayı da sağlayarak psikolojik sahipliğin oluşumuna zemin hazırlayabilmektedir. Bu nedenle, bu tür yapıların psikolojik sahipliğin oluşumu için daha elverişli olduğunu öne sürebilmek mümkündür.

Gerek kültürel bağlamdan etkilenen benlik kavramı, gerekse psikolojik sahipliğin kısmen sosyal süreçlerle oluşan yapısı sebebiyle, kültürel unsurların psikolojik sahipliğin oluşumunda önemli bir rolü olduğunu söyleyebilmek mümkündür (Pierce vd., 2003; s. 25). Nitekim Furby (1980, ss. 39-40), çocukların gelişim süreciyle birlikte sahiplenme dinamiklerinin önemli ölçüde değiştiğini ve sosyal çevrelerinin sahiplenme davranışlarında hem kültürel hem de bireysel farklııkları anlamalarında önemli bir rolü olduğunu belirtmektedir.

Pierce ve arkadaşlarına (2003, ss. 26-28) göre kültür, aynı zamanda bireylerin sahiplik güdülerini ve mekanizmalarının göreceli önemini de etkilemektedir. Örneğin; etkililik ve etkinlik güdüsü, bireyci kültürlerde ait olma güdüsüne kıyasla daha önemliyken, öz kimliğin dışa vurumu toplumcu kültürlerde daha önemli olabilmektedir. Kültür benlik kavramıyla yakından ilişkili olduğundan, hangi hedeflere yöneleceğini de etkilemektedir. Örneğin; toplumcu kültürlerde bireyler sosyal anlamlar taşıyan hedefleri benliklerinin bir parçası olarak görebilmekteyken, bireyci kültürlerde kişisel başarılar daha önemli hale gelebilmektedir. 


\section{Psikolojik Sahipliğin Öncülleri ve Çıktıları}

Daha önce, psikolojik sahiplik kavramının temelleri ve psikolojik sahipliği ortaya çıkaran mekanizmalar etraflıca tartışımıştı. Burada ise; konunun daha iyi anlaşıması adına, özellikle uygulamalı çalışmalardan elde edilen bulgularla, psikolojik sahipliğin öncülleri ve çıktıları üzerinde durulacaktır.

\subsection{Psikolojik Sahipliğin Öncülleri}

Hedefe ilişkin, bireye ilişkin, bağlamsal vb. pek çok etmenin psikolojik sahipliği ortaya çıkarabilme potansiyeli bulunmaktadır. Örneğin; örgüt veya iş sahipliğin hedefindeki varlıklar olduğunda; psikolojik sahipliğin oluşumunu sağlayan güdüleri tatmin edebilme ve mekanizmaların işleyişini kolaylaştırabilme potansiyeli olan özelliklerinin, psikolojik sahipliği ortaya çıkaracağını öne sürmek mümkündür. Benzer şekilde, bireyin kişilik özellikleri gibi bireye ilişkin unsurların da, psikolojik sahipliği ortaya çıkarma potansiyeli bulunmaktadır. Ancak bu bağlamda bakıldığında, psikolojik sahipliğin oluşumuna zemin hazırlayabilecek sayısız öncülünün bulunabileceği kabul edilmelidir. Dolayısıyla bu çalışmada, sadece ampirik verilere dayanan ve psikolojik sahipliği etkilediği bulgulanan öncüllere yer verilecektir. Bu unsurlar ise; farklı liderlik tarzları, iş çevresi yapısı, bireye ilişkin unsurlar, sosyal etkileşim ve iklim esaslı unsurlardır. Bu unsurların her biri, aşağıda kısaca açıklanmaktadır.

\subsubsection{Liderlik}

Örgüt-işgören denkleminde oldukça önemli bir yere sahip olan liderlik üzerine günümüze dek sayısız çalışma yapıımıştır. Dolayısıyla, psikolojik sahiplik yazınında da, liderlikle ilgili çalışmaların son yıllarda hız kazanması şaşırtıcı değildir. Bu çalışmalarda; dönüşümcü liderliğin (Avey vd., 2009; Bernhard ve O'Driscoll, 2011; Ghafoor, Qureshi, Khan ve Hijazi, 2011), edimsel liderliğin (Bernhard ve O’Driscoll, 2011), etik liderliğin (Avey vd., 2012) ve yardımsever liderliğin (Zhu, Chen, Li ve Zhou, 2013) psikolojik sahipliğin öncülleri olduğu bulgulanmıştır. Pasif liderliğin ise (Bernhard ve O’Driscoll, 2011); psikolojik sahiplikle olumsuz bir ilişkisinin olduğu sonucuna varılmıştır.

Psikolojik sahipliğin, dönüşümcü liderlik vasıtasıyla geliştirilme ihtimali bulunmaktadır (Avey vd. 2009; s. 187). İşgörenlere bir vizyon sağlayan, onlara rol model olan ve onları geliştiren dönüşümcü liderler sayesinde, işgörenlerin örgütlerine ve işlerine yönelik güçlü sahiplik hisleri geliştirmeleri oldukça muhtemeldir (Bernhard ve O’Driscoll, 2011; s. 370). Dönüşümcü liderler, işgörenlerin öz etkililiğini arttırarak ve kimliklerinin gelişimini destekleyerek psikolojik sahipliğin oluşmasını sağlamaktadır (Ghafoor vd., 2011; s. 7401). Edimsel liderler ise; amaçlar belirleyerek, onları kontrol ederek ve işgörenleri ödüllendirerek, onların örgüte ve işlerine yönelik psikolojik sahipliklerini geliştirmektedir (Bernhard ve O'Driscoll, 2011; s. 370).

Etik liderlik, psikolojik sahipliğin öncülü olan diğer bir liderlik tipidir. Avey ve arkadaşlarına (2012, s. 30) göre; etik liderler, işgörenlerin işlerine yönelik sorumluluk hislerini tetikleyerek ve adil eylemleriyle bu sorumluluk hislerini geliştirerek, işgörenlerin psikolojik sahipliklerinin artmasını sağlamaktadır. 
Ümit YEŞiL | Ali BANCAR | Gönül BUDAK

Zhu ve arkadaşları (2013), aile işletmelerindeki profesyonel yöneticiler üzerinde gerçekleştirdikleri araştırmada; yardımsever liderliğin ve arkadaşlık bağlarının, işyerindeki yakın ilişki aracılığıyla, yöneticilerin psikolojik sahipliğini etkilediği sonucuna varmışlardır. Yardımsever liderlik, lider sahip ve yönetici arasında yakın ilişkinin kurulmasını sağlayarak, yöneticinin psikolojik sahiplik hislerini geliştirmektedir (Zhu vd. ,2013; ss. 309-310).

\subsection{2. İ̧̧ Çevresinin Yapısı}

İ̧̧ çevresi yapısının üç temel kaynağı olan özerklik, teknoloji ve kararlara katılımın derecelerine göre, işgörenlerin psikolojik sahiplikleri değişmektedir. O'Driscoll ve arkadaşları (2006), iş çevresi yapısının, örgütsel bağılık ve örgütsel vatandaşıkla ilişkisinde psikolojik sahipliğin aracı bir rol üstlendiğini bulgulamışlardır. Onlara göre düşük yapılı iş çevreleri; psikolojik sahipliği ortaya çıkaran mekanizmaları (daha fazla kontrol, hedefi daha iyi tanıma ve hedefe odaklanma fırsatı) kolaylaştırarak, psikolojik sahipliğin gelişmesine zemin hazırlamaktadır (O'Driscoll vd., 2006; s. 388). Örneğin; işgörenlere daha fazla özerklik veren, düşük seviyelerde rutin teknolojinin olduğu ve katılımcı karar vermenin yüksek olduğu iş çevrelerinde, işgörenlerin daha fazla kontrol hissederek işe ve örgüte yönelik psikolojik sahiplik hisleri geliştirmeleri beklenmektedir (O'Driscoll vd., 2006; ss. 409-410). Nitekim Mayhew ve arkadaşları (2007; s. 490); özerkliğin hem işe, hem de örgüte yönelik psikolojik sahipliğin öncülü olduğunu bulgulamıştır.

\subsubsection{Bireye iliş̧kin Unsurlar}

Pierce ve arkadaşlarının (2003) da vurguladığı gibi, bireye ilişkin unsurların psikolojik sahipliğin oluşumunda önemli bir rolü bulunduğu düşünülmektedir. Nitekim Asatryan ve Oh (2008); müşterilerin şirketlere yönelik sahiplik hisleri geliştirmelerinde, özdeşleşme ve ait olmanın psikolojik sahipliğin öncüllerinden ikisi olduğu bulgusuna erişmişlerdir. Müşteriler, kendi değerleriyle şirketin değerlerinin benzer olduklarını düşündüklerinde şirketle özdeşleşmekte ve şirketle ilişkisinin derinleşmesiyle psikolojik sahipliğin ortaya çıkma ihtimali oluşmaktadır (Asatryan ve Oh, 2008; s. 367). Benzer şekilde, müşterilerin sahiplik hisleri, ait olma ihtiyaçlarının tatmin edilebilmesiyle de ortaya çıkabilmektedir (Asatryan ve Oh, 2008; s. 368).

Psikolojik sahipliğin oluşmasında, bireylerin algılarının, tutumlarının ve davranışlarının da önemli bir rolü vardır. Lee ve Chen (2011) sanal dünyalara yönelik psikolojik sahipliği inceledikleri araştırmalarında, psikolojik sahipliği ortaya çıkaran mekanizmalardan yola çıkarak; algılanan kontrol, hedefe odaklanma, bilişsel değer biçme ve duygusal değer biçmenin psikolojik sahipliğin öncülleri olduğu sonucuna varmışlardır. Lee ve Chen'e (2011, s. 277) göre; bireyin hedefi kontrol edebilmesi, zamanını ve enerjisini hedefe harcaması ve hedefe bilişsel ve duygusal olarak bağlanması, psikolojik sahipliği ortaya çıkarmaktadır.

Ghafoor ve arkadaşlarına (2011) göre; bireyin işiyle bütünleşmesi psikolojik sahipliği ortaya çıkaran önemli bir unsurdur. Bireyler işleriyle bütünleştiğinde; işin veya işle ilgili görevlerin gerektirdiği belirli beceri ve yetkinliklere yönelik intiyaçlar doğmakta, birey bu yetkinlik ve becerileri elde ettikçe 
kendine olan güveni ve dolayısıyla öz etkililiği artmakta, bu da onların psikolojik sahiplik hisleri geliştirmelerine neden olmaktadır (Ghafoor vd., 2011; s. 7395). İşgörenin işiyle bütünleşmesi aynı zamanda, onların sorumluluk ve ait olma hislerini arttırarak da, psikolojik sahiplik geliştirmelerini sağlar (Ghafoor vd., 2011; s. 7401).

Ruhsal ve duygusal zekayla içsel kontrol odağı bağlantılarından yola çıkan Kaur, Sambasivan ve Kumar, (2013); bireylerin ruhsal ve duygusal zekalarının, psikolojik sahipliğin öncülleri olduğuna dair bulgular elde etmişlerdir. Kaur ve arkadaşlarına (2013, s. 3195) göre; psikolojik sahiplik, doğası gereği içsel olarak çevreyi etkileme ihtiyacı - kontrol etme isteği- ile yakından ilişkilidir ve bu yönüyle içsel kontrol odağıyla benzeşmektedir. Dolayısıyla, yüksek ruhsal ve duygusal zeka kişisel kontrolü artırmakta ve psikolojik sahipliğin gelişmesini sağlamaktadır.

\subsubsection{Sosyal Etkileşim}

Sosyal etkileşimle ilgili unsurların da, psikolojik sahipliği ortaya çıkarabilme potansiyeli bulunmaktadır. Nitekim Pare, Sicotte ve Jacques, (2006); katılımın alt boyutları olan iletişimin ve genel sorumluluğun, psikolojik sahipliğin öncülleri olduğu sonucuna varmışlardır. Bireyin bir hedefe yönelik sahiplik hisleri geliştirmesinde, onu yakından tanımasının ve bu sayede onu benliğinin bir parçası yapmasının önemli bir yeri vardır. Hedef hakkında daha fazla bilgi sahibi olmanın yollarından biri de, diğer bireylerin hedef hakkındaki bilgilerinden faydalanmaktır. Dolayısıyla, diğer bireylerle iletişim kurmak kaçınılmazdır ve diğer bireylerle kurulan iletişim zaman ve enerji harcamayı gerektirmektedir. Benzer şekilde, ortak projelerde, bireyler sorumlulukları paylaşmaktadır. Bu bağlamda, iletişimsel aktivitelerin ve genel sorumluluğun psikolojik sahipliği ortaya çıkarması şaşırtıcı değildir (Pare vd., 2006; s. 199).

İletişim ve genel sorumluluğa ek olarak, sosyal ilişkilerden doğan yakınlık da psikolojik sahipliği ortaya çıkarabilmektedir. Zhu ve arkadaşları (2013), yardımsever liderlik ve arkadaşlık bağlarının, sahip ve yönetici arasındaki yakın ilişkileri ortaya çıkararak psikolojik sahipliğin gelişmesine yol açtığına yönelik sonuçlar elde etmişlerdir. Özetle, sosyal etkileşimler psikolojik sahipliği ortaya çıkarabilecek önemli bir faktör olarak görülmektedir.

\subsection{5. Örgüt İklimi}

Psikolojik sahipliği ortaya çıkaran mekanizmalar göz önünde bulundurulduğunda, iklimin bireylerin psikolojik sahiplikleri üzerinde ne denli önemli etkileri olabileceği kolaylıkla fark edilecektir. Bireylerin; işlere, projelere, kararlara veya finansal sahiplik planlarına katılımları üzerine yapılan pek çok çalışmada, özellikle kontrol mekanizması vasıtasıyla psikolojik sahipliğin ortaya çıktığı görülmektedir. Örneğin Pare ve arkadaşları (2006); hekimlerin aktif katılımının, sistem üzerinde daha fazla kontrolleri olduğunu düşünmelerini sağlayarak sisteme yönelik sahiplik hisleri geliştirmelerini sağladığını vurgulamaktadır. Barki, Pare ve Sicotte (2008), kullanıcıların katılımları vasıtasıyla bilişim tek-

nolojilerine yönelik, Asatryan ve Oh (2008) ise; müşterilerin katılımları vasıtasıyla firmalara yönelik psikolojik sahiplik geliştirdiklerini bulgulamışlardır. Benzer şekilde, kararlara katılım (Chi ve Han, 2008; Han, Chiang ve Chang, 2010; Liu vd., 2012) ve finansal sahiplik planlarına katılım (Wagner, 
Ümit YEŞiL | Ali BANCAR | Gönül BUDAK

Parker ve Christiansen, 2003; Chi ve Han, 2008) da, psikolojik sahipliğin öncülleri olarak ele alınmaktadır. Buradan yola çıkarak, katıımı (aktif katılım, bilgiye erişim, kararlara katılım veya finansal sahiplik planlarına katılım) destekleyen bir iklimin, psikolojik sahipliği ortaya çıkaracağını söyleyebilmek mümkündür. Bunlara ek olarak, öz belirlenimi destekleyen bir iklimin (Wagner vd., 2003) ve kendi kendini yöneten takım ikliminin (Liu vd., 2012) de, psikolojik sahipliğin öncülleri olduğu bulgulanmıştır.

\subsection{Psikolojik Sahipliğin Çıktıları}

Psikolojik sahipliğin örgütsel çıtılar üzerinde olumlu veya olumsuz etkileri olabilmektedir. Ancak temelde olumlu veya olumsuz çıktıları ortaya çıkaran durumun, psikolojik sahipliğin iki eşsiz ve bağımsız şeklinden kaynaklandığını öne sürebilmek mümkündür. Geliştirici psikolojik sahiplik; olumlu çıktıların kaynağı olabilirken, önleyici psikolojik sahiplik ise; genellikle olumsuz sonuçlarla ilişkilendirilmektedir. Bununla beraber istisnai durumlar da, söz konusu olabilmektedir. Örneğin; önleyici psikolojik sahiplik, bireysel çalışmanın önemli olduğu durumlarda olumlu çıktılar yaratabilmekteyken, takım çalışmasının gerekli olduğu durumlarda olumsuz sonuçlara neden olabilmektedir.

İşörenlerin tutum ve davranışlarını tahmin etmek ve anlamak söz konusu ise; psikolojik sahiplik, örgütsel bağlıı̆̆a ve iş doyumuna kıyasla daha açıklayıcı olmaktadır (Van Dyne ve Pierce, 2004; s. 454). Psikolojik sahipliğin bu ayırt edici yönü, örgütsel çıktılar üzerinde ne denli önemli sonuçlar doğurabileceğini göstermektedir. Nitekim yapılan araştırmalar psikolojik sahipliğin; işgörenlerin tutum ve/veya davranışlarını (Wagner vd., 2003; Van Dyne ve Pierce, 2004; O’Driscoll vd., 2006; Avey vd., 2009; Han vd., 2010; Bernhard ve O’Driscoll, 2011; Avey vd., 2012; Liu vd., 2012; Kaur vd., 2013; Sieger, Zellweger ve Aquino , 2013; Zhu vd., 2013) etkilediğini ve bireysel çıktıları arttırarak örgütsel performansa (Wagner vd., 2003; Ghafoor vd., 2011; Sieger vd., 2013) olumlu katkıları olduğunu göstermektedir.

İ̧̧örenler, örgütlerine ve/veya işe yönelik sahiplik hisleri geliştirdiklerinde; örgütsel bağlılıkları, iş tatminleri, örgütte kalma niyetleri, örgüt esaslı öz saygıları vb. tutumları olumlu olmaktadır. Bu olumlu tutumlar çoğu zaman, rol davranışlarını (Bernhard ve O'Driscoll, 2011; Kaur vd., 2013) ve ekstra rol davranışlarını (Van Dyne ve Pierce, 2004; O’Driscoll vd., 2006; Avey vd., 2009; Bernhard ve O’Driscoll, 2011; Liu vd., 2012; Zhu vd., 2013) da etkilemektedir. Örneğin; psikolojik sahiplik, örgütsel bağ|ılığı geliştirerek işgörenlerin özgeci ruhunu tetiklemekte ve ileri teknoloji üreten firmalar açısından son derece önemli olan bilgi paylaşımı davranışlarına katkı sağlamaktadır (Han vd., 2010; s. 2218).

Psikolojik sahipliği vekalet teorisi penceresinden inceleyen Sieger ve arkadaşlarına (2013) göre; psikolojik sahiplik, finansal sahipliğin olmadığı durumlarda asılların ve vekillerin çıkarlarını bütünleştirebilmektedir. Nitekim bu çalışmada; psikolojik sahipliğin, bireysel düzeyde girişimcilik davranışını etkileyerek firma performansını arttırdığı sonucuna varılmıştır. 
Psikolojik sahiplik, yeni bir teknoloji veya sistemin benimsenmesinde (Pare vd., 2006; Barki vd.; 2008) de önemli bir role sahiptir. Psikolojik sahiplik, kullanıcıların yeni bir teknoloji veya sisteme yönelik algılarını olumlu yönde etkileyerek, yeniliğin entegrasyonunu kolaylaştırmaktadır. O halde psikolojik sahipliğin, değişimin benimsenmesinde önemli bir araç olarak kullanabileceğini söyleyebilmek mümkündür.

Psikolojik sahiplik, hem çıktılar üzerinde doğrudan olumlu bir etki yaratmakta, hem de tükenmişlik ve sapkın davranışlar gibi çıktıları olumsuz yönde etkileyebilecek tutum ve davranışların etkilerini azaltarak, dolaylı olarak çıktılara olumlu bir katkı yapmaktadır. Örneğin Kaur ve arkadaşları (2013, s. 3198); psikolojik sahipliğin, hemşirelerin bakım davranışlarına doğrudan etkisinin yanında, tükenmişliğin olumsuz etkisini azaltarak dolaylı bir katkı yaptığını belirlemişlerdir. Benzer şekilde, Avey ve arkadaşları (2009, s. 184) da, psikolojik sahipliğin sapkın davranışlarla olumsuz bir ilişkisi olduğunu bulgulamışlardır.

Pierce ve arkadaşlarına (2009, ss. 487-490) göre; iş tasarımı-psikolojik sahiplik bağlantısı göz önüne alındığında; genellikle içsel motivasyon, iş tatmini, kalite performansı ve devamlılık gibi olumlu çıktılar ortaya çıksa da, özellikle bölgeci sahipliğin olumsuz sonuçları da doğurabilmesi sebebiyle; örgüt üyelerinin sapkın davranışlar sergilemesi, izolasyonu veya bölgelerini korumaya fazla odaklanarak örgütsel amaçlardan uzaklaşabilmeleri gibi istenmeyen sonuçlar da ortaya çıkabilmektedir.

Brown, Crossley ve Robinson (2014); psikolojik sahipliğin karanlık tarafını inceledikleri çalışmada, iş çevresindeki güvenin kritik bir rolü olduğu sonucuna varmışlardır. Onlara göre iş çevresinde güvenin yüksek olması; hem psikolojik sahiplikle birlikte gelebilecek bölgeci davranışların azalmasına, hem de bölgeci davranışlar gösteren bireylerin takıma olan katkılarının diğer üyeler tarafından düşük olarak değerlendirilmesine yol açmaktadır.

Özetle, psikolojik sahipliğin geliştirici yönü, örgütler açısından son derece olumlu sonuçlar yaratabilmektedir. Buna karşın, psikolojik sahipliğin karanlık tarafı olan önleyici psikolojik sahiplik ise; örgütler açısından istenmeyen sonuçlara yol açabilmektedir. Ancak teoride önleyici sahipliğin; değişime direnç, takım çalışmasının zorlaşması, sabotaj gibi sapkın davranışlar, sahiplenilen nesnenin kaybı durumunda deneyimlenebilecek olumsuz durumlar (Pierce vd., 2001; ss. 303-304), çatışma, izolasyon ve bireysel amaçlara fazla odaklanma (Brown vd., 2005; ss. 586-588) gibi pek çok olumsuz sonuç yaratabileceği öngörülse de; önleyici psikolojik sahipliğe yönelik araştırmalar sınırlı sayıdadır.

\section{Tartışma ve Sonuç}

Bu çalışmada; psikolojik sahipliğin ne olduğu, nasıl oluştuğu ve örgütler açısından ne gibi faydalar sağlayabileceği soruları cevaplanmaya çalışılmıştır. Bireylerin hedeflere yönelik sahiplenici hisler geliştirdikleri, psikolojik olarak deneyimlenen bir olgu (Van Dyne ve Pierce, 2004; s. 439) olarak tanımlanan psikolojik sahiplik kavramı, sahiplenmeye dayalı doğasıyla diğer yapılardan farklılaşmakta ve işgören tutum ve davranışlarını anlamak söz konusu olduğunda, iş doyumu ve örgütsel bağlılık gibi yapılara kıyasla daha açıklayıcı olmaktadır. 
Psikolojik sahiplik, bireye özgü güdülerle yakından ilişkili olduğundan çok boyutlu bir yapıya sahiptir. Etkililik ve etkinlik, öz kimlik, ait olma, hesap verebilme, sorumluluk ve özerklik geliştirici psikolojik sahipliğin alt boyutlarıyken, bölgecilik ise önleyici psikolojik sahipliğin tek boyutu olarak ele alınmaktadır. Ancak, özellikle kültürel bağlamın bireylerin psikolojik sahipliği üzerindeki etkisi göz önünde bulundurulduğunda, farklı kültürlerde psikolojik sahipliğin ölçülmesine yönelik sorunlar da ortaya çıkabilmektedir. Nitekim Olckers'ın (2013) ölçek geliştirme çalışmasında, Güney Afrika kültüründe psikolojik sahipliğin; üçü geliştirici (sorumluluk, öz kimlik ve özerklik) ve biri önleyici (bölgecilik) sahipliğe ait olmak üzere dört boyutlu bir yapı olarak ortaya çıkması, psikolojik sahipliğin ölçümünde emik yaklaşımın önemli olabileceğini göstermektedir.

Psikolojik sahiplikle ilgili bir diğer önemli nokta ise; örgüte ve işe yönelik psikolojik sahipliğin birbirlerinden farklı iş tutumları olması (Mayhew vd., 2007; ss. 492-493) ve dolayısıyla çıktılarının da farklı olabilmesidir. Örneğin; işe yönelik psikolojik sahiplik, iş doyumuyla ilişkiliyken, örgüte yönelik psikolojik sahiplik, duygusal bağlıık ve iş doyumuyla ilişkili olabilmektedir (Mayhew vd., 2007; s. 493). Bu sebeple araştırmalar kurgulanırken, işgörenlerin örgüte ve işe yönelik sahipliklerinin farklı tutumlar oldukları göz önünde bulundurulmalıdır. Bu durumu, psikolojik sahipliğin oluşum sürecinde, hedefe ilişkin unsurlarla ilişkilendirerek açıklayabilmek mümkündür. Sahipliğin hedefindeki varlıkların özellikleri, bireylerin sahiplik hislerini de etkilemektedir. Dolayısıyla örgüt ve iş birbirlerinden farklı hedefler olduğundan, sahipliği ortaya çıkaran güdüleri tatmin edebilecek ve oluşum mekanizmalarını kolaylaştırabilecek özelliklerinin de birbirlerinden farklı olabilmesi olasıdır. Örneğin; alt kademelerdeki işgörenlerin yaptıkları işle ilgili daha fazla bilgi sahibi oldukça, işe yönelik psikolojik sahiplik geliştirmeleri olasıyken; örgütle ilgili üst düzey bilgilere erişememeleri sebebiyle örgüt hakkındaki bilgilere erişimleri kısıtlı olmakta ve dolayısıyla, hedefi yakından tanıma mekanizması işlememektedir. Bu durumda, işgörenin örgütü tanıması vasıtasıyla, örgüte yönelik psikolojik sahiplik geliştirmesi pek olası görünmemektedir.

Her bilimsel araştırmada olduğu gibi, psikolojik sahiplik üzerine yapılan araştırmaların yapı ve örneklem bakımından farkılı̆̆ı da, elde edilen sonuçların farklı olmasına neden olabilmektedir. Örneğin; bazı araştırmacılar (Bernhard ve O'Driscoll, 2011; Kaur vd., 2013) psikolojik sahipliğin rol davranışlarıyla ilişkili olduğuna dair bulgular elde etmişken, diğerleri; ya psikolojik sahiplik ve rol davranışları arasında ilişki bulunsa da, demografik değişkenler hesaba katıldığında bu ilişkinin anlamsız olduğu sonucuna varmış (Van Dyne ve Pierce, 2004); ya da bu ilişkiye yönelik herhangi bir destek bulamamışlardır (Mayhew vd., 2007; s. 493).

Psikolojik sahipliğin olası çıktıları ise; tartışıması gereken bir diğer konudur. Psikolojik sahiplik üzerine yapılan çalışmaların büyük çoğunluğu, geliştirici sahiplik üzerinde durmakta, ancak önleyici sahipliğin doğurabileceği olumsuz sonuçlar neredeyse hiç incelenmemektedir. Bu sebeple, önleyici sahiplik ve bölgeci davranışlar üzerine daha fazla çalışma yapılması gerekmektedir. 
Örgütsel yapı ve kültür gibi bağlamsal faktörlerin de psikolojik sahipliğin oluşumundaki rolünün incelenmesi gerekmektedir. Nitekim Liu ve arkadaşları (2012), Çin kültüründe; kontrol, psikolojik sahiplik ve bireysel çıktılar arasındaki (örgüt kaynaklı öz saygı, duygusal bağ|ıık ve örgütsel vatandaşlık) ilişkide, güç mesafesinin düzenleyici bir rolü olduğunu bulgulamışlardır. Bulgulara göre, güç mesafesi düşük bireylerin psikolojik sahipliğinin, kontrol ve bireysel çıktılar arasındaki ilişkide önemli bir rolü varken, aynı durum güç mesafesi yüksek bireyler için geçerli değildir.

Örgütsel yapı ve kültür gibi bağlamsal faktörlerin yanında; birey, takım ve örgüt gibi farklı düzeylerin de psikolojik sahipliğin oluşumundaki rolünün incelenmesi gerekmektedir. Liu ve arkadaşları (2012, ss. 870-871); psikolojik sahipliğin doğası gereği bireysel bir deneyim olmasından dolayı, öncüllerinin de genellikle bireysel düzeyde kavramlaştırıldığını; ancak takım düzeyi gibi daha yüksek düzeylerin de incelenmesi gerektiğini öne sürmektedirler. Nitekim Liu ve arkadaşları (2012), kendi kendini yöneten takım ikliminin psikolojik sahipliğin öncüllerinden biri olduğunu bulgulamışlardır.

Sonuç olarak, psikolojik sahiplik teorisi, yapılan katkılarla her geçen gün daha da zenginleşmekte ve örgüt ve yönetim alanında ele alınan pek çok noktaya ışık tutmaktadır. Ancak diğer ülkelerin aksine, ne yazık ki ülkemizde psikolojik sahiplik üzerine yapılan çalışmalar oldukça sınırlı sayıda kalmıştır. Bu nedenle, özellikle Türk kültüründe psikolojik sahipliği anlamaya yönelik çalışmalar yapılmasıyla, ülkemizdeki işgörenlerin işe ve işletmeye yönelik tutum ve davranışlarının daha iyi anlaşılmasının sağlanacağına ve bu alanda yapılacak çalışmaların artmasıyla, evrensel bilime de kendi ülke modelimizle önemli katkılar yapılacağına inanılmaktadır.

\section{Kaynaklar}

Asatryan, V. S., \& Oh, H. (2008). Psychological ownership theory: An exploratory application in the restaurant industry. Journal of Hospitality \& Tourism Research, 32: 363-386.

Avey, J. B., Avolio, B. J., Crossley, C. D., \& Luthans, F. (2009). Psychological ownership: Theoretical extensions, measurement and relation to work outcomes. Journal of Organizational Behavior, 30(2), 173-191.

Avey, J. B., Wernsing, T. S., \& Palanski, M. E. (2012). Exploring the process of ethical leadership: The mediating role of employee voice and psychological ownership. Journal of Business Ethics, 107(1), 21-34.

Barki, H., Paré, G., \& Sicotte, C. (2008). Linking IT implementation and acceptance via the construct of psychological ownership of information technology. Journal of Information Technology, 23(4), 269-280.

Beggan, J. K., \& Brown, E. M. (1994). Association as a psychological justification for ownership. (PROQUEST).

Belk, Russell W. (1988). Possessions and the Extended Self. Journal of Consumer Research. Vol. 15, Sept. 1988, 139-168. 
Ümit YEŞiL | Ali BANCAR | Gönül BUDAK

Bernhard, F., \& O'Driscoll, M. P. (2011). Psychological ownership in small family-owned businesses: Leadership style and nonfamily-employees' work attitudes and behaviors. Group \& Organization Management, 36(3), 345-384.

Brown, G., Crossley, C., \& Robinson, S. L. (2014). Psychological Ownership, Territorial Behavior, and Being Perceived as a Team Contributor: The Critical Role of Trust in the Work Environment. Personnel Psychology, 67(2), 463-485.

Brown, G., Lawrence, T. B., \& Robinson, S. L. (2005). Territoriality in organizations. Academy of Management Review, 30(3), 577-594.

Chi, N. W., \& Han, T. S. (2008). Exploring the linkages between formal ownership and psychological ownership for the organization: The mediating role of organizational justice. Journal of Occupational and Organizational Psychology, 81(4), 691-711.

Furby, L. (1980). The origins and early development of possessive behavior. Political Psychology, $30-$ 42.

Ghafoor, A., Qureshi, T. M., Khan, M. A., \& Hijazi, S. T. (2011). Transformational leadership, employee engagement and performance: Mediating effect of psychological ownership. African journal of business management, 5(17), 7391-7403.

Han, T. S., Chiang, H. H., \& Chang, A. (2010). Employee participation in decision making, psychological ownership and knowledge sharing: Mediating role of organizational commitment in taiwanese high-tech organizations. The International Journal of Human Resource Management, 21(12), 2218-2233.

Kaur, D., Sambasivan, M., \& Kumar, N. (2013). Effect of spiritual intelligence, emotional intelligence, psychological ownership and burnout on caring behaviour of nurses: a cross-sectional study. Journal of clinical nursing, 22(21-22), 3192-3202.

Lee, Y., \& Chen, A. N. (2011). Usability design and psychological ownership of a virtual world. Journal of Management Information Systems, 28(3), 269-308.

Litwinski, L. (1947). The psychology of “mine". Philosophy, 22(83), 240-251.

Liu, J., Wang, H., Hui, C., \& Lee, C. (2012). Psychological ownership: how having control matters. Journal of Management Studies, 49(5), 869-895.

Mayhew, M. G., Ashkanasy, N. M., Bramble, T., \& Gardner, J. (2007). A study of the antecedents and consequences of psychological ownership in organizational settings. The Journal of social psychology, 147(5), 477-500.

Mulgan, R. (2000). 'Accountability': An Ever-Expanding Concept?. Public administration, 78(3), 555573. 
O'driscoll, M. P., Pierce, J. L., \& Coghlan, A. M. (2006). The psychology of ownership work environment structure, organizational commitment, and citizenship behaviors. Group \& Organization Management, 31(3), 388-416.

Olckers, C. (2013). Psychological ownership: Development of an instrument.SA Journal of Industrial Psychology, 39(2), 1-13.

Olckers, C., \& Du Plessis, Y. (2012). Psychological ownership: A managerial construct for talent retention and organisational effectiveness.

Paré, G., Sicotte, C., \& Jacques, H. (2006). The effects of creating psychological ownership on physicians' acceptance of clinical information systems. Journal of the American Medical Informatics Association, 13(2), 197-205.

Pierce, J. L., \& Furo, C. A. (1991). Employee ownership: Implications for management. Organizational Dynamics, 18(3), 32-43.

Pierce, J. L., Jussila, I., \& Cummings, A. (2009). Psychological ownership within the job design context: revision of the job characteristics model. Journal of Organizational Behavior, 30(4), 477-496.

Pierce, J. L., Kostova, T., \& Dirks, K. T. (2001). Toward a theory of psychological ownership in organizations. Academy of Management Review,26(2), 298-310.

Pierce, J. L., Kostova, T., \& Dirks, K. T. (2003). The state of psychological ownership: Integrating and extending a century of research. www. researchgate.net. (25/10/2014).

Pierce, J. L., O'driscoll, M. P., \& Coghlan, A. M. (2004). Work environment structure and psychological ownership: the mediating effects of control. The Journal of Social Psychology, 144(5), 507-534.

Pierce, J. L., \& Rodgers, L. (2004). The psychology of ownership and worker-owner productivity. Group \& Organization Management, 29(5), 588-613.

Pierce, J. L., Rubenfeld, S. A., \& Morgan, S. (1991). Employee ownership: A conceptual model of process and effects. Academy of Management review,16(1), 121-144.

Ryan, R. M., \& Deci, E. L. (2006). Self-Regulation and the Problem of Human Autonomy: Does Psychology Need Choice, Self-Determination, and Will?.Journal of personality, 74(6), 15571586.

Sieger, P., Zellweger, T., \& Aquino, K. (2013). Turning Agents into Psychological Principals: Aligning Interests of Non-Owners through Psychological Ownership. Journal of Management Studies, 50(3), 361-388. 
Van Dyne, L., Cummings, L.L., and Parks, J.M., (1995). Extra-role behaviors: In pursuit of construct and definitional clarity (A bridge over muddied waters). In L. L. Cummings \& B. M. Staw (Eds.), Research in organizational behavior (Vol. 17, pp. 215-285). Greenwich, CT: JAI Press.

Van Dyne, L., \& Pierce, J. L. (2004). Psychological ownership and feelings of possession: three field studies predicting employee attitudes and organizational citizenship behavior. Journal of Organizational Behavior, 25(4), 439-459.

Vandewalle, D., Van Dyne, L., \& Kostova, T. (1995). Psychological ownership: An empirical examination of its consequences. Group \& Organization Management, 20(2), 210-226.

Wagner, S. H., Parker, C. P., \& Christiansen, N. D. (2003). Employees that think and act like owners: Effects of ownership beliefs and behaviors on organizational effectiveness. Personnel Psychology, 56(4), 847-871.

Zhu, H., Chen, C. C., Li, X., \& Zhou, Y. (2013). From Personal Relationship to Psychological Ownership: The Importance of Manager-Owner Relationship Closeness in Family Businesses. Management and Organization Review, 9(2), 295-318. 